\title{
Assessing Master Gardeners' Priorities
}

\author{
Diane Relf and Alan McDaniel
}

Additional index words. demographics, volunteer activities, training and management

Summary. A survey of Virginia Master Gardeners ( $\mathrm{N}=$ 188) indicates that answering individual questions and providing educational programs designed to change individuals' behavior were equally important and ranked as number 1 priority for volunteer activity. In terms of training and management, local training programs had the highest importance ranking, with participation in local associations ranking second in importance. Social activities had the lowest importance. Annual training was viewed as primarily the agents' responsibility. However, daily man-agement, record keeping, and related activities were viewed as Master Gardener responsibilities in cooperation with agents.

$\mathrm{T}$ he Master Gardener (MG) program originated at Washington State Univ. in 1972 with the purpose of addressing the emerging phenomena of too many gardening questions and not enough staff to answer them. The program was based on the concept that most gardening questions can be answered by experienced, trained volunteers and experienced gardeners willing to share the load of the extension office in exchange for specialized training. Training was provided in basic horticulture, with the agreement that a specified number of hours of volunteer time would be paid back to the extension office by answering questions (Warner, 1978).

In Washington State in 1977 (Warner, 1978), most of the reported volunteer hours were at MG clinics setup at major shopping centers, libraries, gardening events, and county fairs. However, a report that same year from Cornell indicated that MGs there also were working with the aging and blind, conducting soil tests, judging at fairs, and otherwise expanding the types of services volunteered to extension (Warner, 1978).

MGs active as volunteers in California in 1981 responded to a survey that indicated the potential for community development of such volunteer programs. Indicators of this unanticipated impact of the program include: $64 \%$ agreed with the statement "I gained a considerable amount of new knowledge in areas beside gardening." Of these respondents, $84 \%$ gained knowledge related to where to find information, $64 \%$ gained knowledge about agricultural issues and community resources, $58 \%$ about government support resources, and $55 \%$ about ways to work with the public (Grieshop, 1984).

At present (Flagler, 1992), 45 states and four provinces have $>45,000 \mathrm{MGs}$. This growth of the program has resulted in continued change in programming philosophy. One area in which there has been a shift in philosophy is in

Department of Horticulture, Virginia Polytechnic Institute and State University, Blacksburg, VA 24061. 
attempts to increase retention of MGs. This is accomplished in several ways (Stouse, 1992); the most important is by discouraging the volunteers from thinking of hours as "payback." Instead, volunteer time is emphasized as an opportunity for continued learning. In addition, advisory boards and committee structures lead toward increased selfmanagement and provide a feeling of ownership of the program. Advanced training and meaningful, diverse volunteer opportunities also increase retention.

As part of an evaluation and planning effort, a survey of 500 (a random sample of the 2000 on the statewide mailing list) Virginia Master Gardeners (VMGs) was conducted in 1992. The survey was developed based on discussions with MGs and agents to determine the priorities for programming, the perceived importance of certain MG activities, and the roles of agents and MGs in the management of programs. Within the designated time period, 188 surveys were returned completed (39\%) and 20 were undeliverable. No reminder or follow-up was used to increase the response rate.

The survey provided a demographic picture (Table 1 ) of VMGs with interesting insights into changes in participants compared to the only other demographic of MGs found in print (Grieshop, 1984). It is not possible to tell how much of the difference can be attributed to geographic location (Virginia vs. California) and how much to the 11-year difference in the time of conducting the surveys. However, in Virginia, there was a higher percentage of women (64\% vs. $58 \%$ ) and non-working volunteers $(50 \%$ vs. $45 \%)$, an apparent increase in older (55\% over 50 vs. $28 \%$ over 55$)$ and higher-income volunteers (34\% over $\$ 50,000$ vs. $18 \%$ over $\$ 40,000)$, and fewer non-white volunteers ( $5 \%$ vs. $10 \%)$. The figures on the percentage of VMGs under the age of $25(0 \%)$ and the percent of Table 1. Demographics $(\mathrm{N}=188)$.

\begin{tabular}{|c|c|}
\hline Variable & Percentage \\
\hline \multicolumn{2}{|l|}{ Age } \\
\hline Under 25 & 0 \\
\hline 25 to 50 & 45 \\
\hline Over 50 & 55 \\
\hline \multicolumn{2}{|l|}{ Gender } \\
\hline Female & 64 \\
\hline Male & 36 \\
\hline \multicolumn{2}{|l|}{ National origin } \\
\hline Asian American & 1 \\
\hline American Indian & 1 \\
\hline African American & 3 \\
\hline -European American & 95 \\
\hline \multicolumn{2}{|l|}{ Income } \\
\hline Less than $\$ 20,000$ & 16 \\
\hline$\$ 20,000$ to $\$ 50,000$ & 50 \\
\hline More than $\$ 50,000$ & 34 \\
\hline \multicolumn{2}{|l|}{ Employment } \\
\hline Full-time & 30 \\
\hline Part-time & 20 \\
\hline Retired"' & 31 \\
\hline In the home & 19 \\
\hline \multicolumn{2}{|c|}{ Years as a Master Gardener } \\
\hline Less than 2 years & 24 \\
\hline 2 to 4 years & 42 \\
\hline More than 4 years & 35 \\
\hline
\end{tabular}
African Americans $(3 \%)$ are of particular significance and concern in light of a 1991 survey by Independent Sector (Voluntary Action, 1992 ) reporting on a national study of volunteering that $48 \%$ of Americans ages 18 to 25 and $43 \%$ of African Americans volunteered that year. The Virginia Extension MG program does not appear to be reaching its full audience and, therefore, is missing important clientele in the community with the resultant outreach programs.

\section{Programming priorities}

Two sections of the survey related to the programming priorities of the VMGs in their service or volunteer activities. First, they were asked to rank six program areas, with 1 being most important and 6 least important (Table 2). No repetition of numbers was allowed. The analysis of mean values and their standard errors indicates that "response to individual inquiry" through plant clinics, telephones, etc., and "change the behavior of individuals" through educational programs were considered to be statistically of equal importance. "Teaching youth to respect nature and the environment through gardening" was ranked much higher than the next, "establishing and maintaining demonstration gardens," which was ranked higher than the final two of statistically equal value, "maintenance of histonc and public gardens" and "horticultural therapy programs."

To determine further the perceived value of these program areas (Table 3), the respondents were asked to rate activities on a Likert-type scale of 1 to 4 , with 1 meaning very important and 4 meaning not at all important. All of the activities clearly were rated as important, and the ranking of the activities based on the ratings followed the same overall pattern as the original ranking of program area. For example, when a demonstration garden clearly was defined as environmental education demonstration, its rated importance moved it into the same ranking as other environmental education programs. Plant clinics (the original focus of MG activities) ranking beneath environmental programs may be an indication that the significant increase in number of volunteers provides for many more programmatic options than the original smaller numbers of volunteers.

The involvement of VMGs in actual, hands-on garden

Table 2. Priorities for Virginia Master Gardener programs. Ranking of individual's perception of importance of six program areas, $1=$ most important and $6=$ least important. No repetition of number was allowed. Lines indicate groupings that are statistically the same based on analysis of mean values and their standard errors.

\begin{tabular}{|c|c|c|}
\hline \multicolumn{2}{|c|}{ Rank } & \multirow[b]{2}{*}{ Program } \\
\hline Average & SE & \\
\hline 2.38 & 0.12 & $\begin{array}{l}\text { Providing horticultural information in response } \\
\text { to individual inquiry to help people take care } \\
\text { of the environment and their landscape invest- } \\
\text { ments and gain the benefits of plants around } \\
\text { them (i.e., telephones, plant clinics, etc.). }\end{array}$ \\
\hline 2.58 & 0.11 & $\begin{array}{l}\text { Presenting programs to change the behavior of } \\
\text { individuals with emphasis on environmen- } \\
\text { tally sound practices (adult and community } \\
\text { education programs working cooperatively } \\
\text { with other agencies). }\end{array}$ \\
\hline 2.83 & 0.09 & $\begin{array}{l}\text { Protecting the future by teaching youth to re- } \\
\text { spect nature and the environment through } \\
\text { gardening. }\end{array}$ \\
\hline 1.12 & 0.11 & $\begin{array}{l}\text { Establishing and maintaining demonstration } \\
\text { gardens or sites to show people how to garden } \\
\text { successfully while protecting the environment. }\end{array}$ \\
\hline 4.64 & 0.11 & $\begin{array}{l}\text { Protecting our heritage through hands-on } \\
\text { work and maintenance of historic and public } \\
\text { gardens. }\end{array}$ \\
\hline 4.82 & 0.11 & $\begin{array}{l}\text { Enhancing the quality of life for elderly, dis- } \\
\text { abled, and other special populations in Vir- } \\
\text { ginia through horticultural therapy programs. }\end{array}$ \\
\hline
\end{tabular}


Table 3. Virginia Master Gardener community and educational activities. Ranking of perceived value of specific activities on a Likerttype scale of 1 to $4(1=$ very important; $4=$ not at all important $)$. Lines indicate groupings that are statistically the same based on analysis of mean values and their standard errors.

\begin{tabular}{|c|c|c|}
\hline \multicolumn{2}{|c|}{ Rank } & \\
\hline Average & SE & Activity \\
\hline 1.24 & 0.04 & Answer horticultural inquiries \\
\hline 1.39 & 0.05 & $\begin{array}{l}\text { Environmental education programs: water } \\
\text { quality }\end{array}$ \\
\hline 1.45 . & 0.05 & Environmental education demonstrations \\
\hline 1.48 & 0.05 & Environmental education programs: IPM \\
\hline 1.49 & 0.05 & $\begin{array}{l}\text { Environmental education programs: yard waste } \\
\text { management }\end{array}$ \\
\hline 1.69 & 0.05 & Plant clinics \\
\hline 1.78 & 0.05 & Horticulture gardens/arboreta/botanic gardens \\
\hline 1.79 & 0.05 & $\begin{array}{l}\text { Public and historic sites consulting, supervis- } \\
\text { ing youth or club involvement }\end{array}$ \\
\hline 1.81 & 0.06 & 4-H/Youth/School/Programs \\
\hline 1.85 & 0.06 & Giving lectures \\
\hline 1.97 & 0.06 & Historic gardens-actual gardening work \\
\hline 2.03 & 0.06 & Public sites-actual gardening work \\
\hline 2.23 & 0.06 & Clerical support in extension office \\
\hline 2.27 & 0.07 & Horticultural therapy \\
\hline 2.41 & 0.06 & Garden shows \\
\hline
\end{tabular}

work has been a major area of debate, particularly among extension agents, some of whom feel that it is a misuse of VMG skills and training and not within extension's mission. However, VMGs clearly believe that it is important. The educational value may be seen in that historic and public sites present opportunities to demonstrate proper gardening techniques to different audiences than most extension program locations.

VMGs have provided a great deal of clerical support in extension offices in these times of budget reductions; however, this area does not rank as high a priority as those activities using their horticultural skills.

Although horticultural therapy (HT) programs are ranked only above garden shows in importance as a VMG

Table 4. Virginia Master Gardener activities related to training and management. Ranking of perceived value of certain activities on a

Linkert-type scale of 1 to $4(1=$ very important; $4=$ not at all impor-

tant). Lines indicate groupings that are statistically the same based on analysis of mean values and their standard errors.

\begin{tabular}{|c|c|c|}
\hline \multicolumn{2}{|c|}{ Rank } & \multirow[b]{2}{*}{ Activities } \\
\hline Average & $\mathrm{SE}$ & \\
\hline 1.43 & 0.05 & Annual training \\
\hline$\overline{1.61}$ & 0.05 & Local association participation \\
\hline$\overline{1.73}$ & 0.06 & PR (Master Gardener success stories) \\
\hline 1.79 & 0.06 & Monthly educational programs \\
\hline 1.82 & 0.05 & Newsletter/correspondence \\
\hline 1.90 & 0.06 & $\begin{array}{l}\text { Record keeping to document the impact of } \\
\text { Master Gardeners }\end{array}$ \\
\hline 1.95 & 0.06 & PR (importance of Consumer Horticulture) \\
\hline 2.13 & 0.06 & $\begin{array}{l}\text { Field trips-site selection and travel arrange- } \\
\text { ments }\end{array}$ \\
\hline 2.29 & 0.06 & Telephone network \\
\hline 2.34 & 0.06 & State association representative \\
\hline 2.35 & 0.06 & $\begin{array}{l}\text { Organizing events with regional Master Gar- } \\
\text { dener groups }\end{array}$ \\
\hline 2.82 & 0.06 & Social activities \\
\hline
\end{tabular}

activity, they still are seen on the positive or important end of the scale. Flagler (1992) reports that 21 states had HT activities, with 374 MGs involved serving 3591 clients. The figures are probably consistent with its priority ranking... small, but valuable, particularly within the context of a program that has a more narrow focus than the others listed.

\section{Training and management}

Two sections of the survey addressed issues related to the training and management of VMGs. Respondents again were asked to rate the importance of certain activities on a Likert-type scale of 1 to 4 ; these were then ranked from most important to least (Table 4). Locally based activities ranked highest, while regional and state activities ranked lowest, except for social activities, which were the only activities ranked on the not-important end of the scale.

Respondents were requested to indicate the responsibility for certain VMG management activities (Table 5). Interestingly, the item ranked as most important from the first section of the survey, annual training, was seen as primarily the agent's responsibility, while the least important, state advisory board participation, was primarily the VMG's responsibility. The most striking feature of this table is the degree to which VMGs feel responsibility for managing the program. Once the training has been completed with leadership from the agent, VMGs see themselves playing increasingly strong roles. Those activities that involve VMG interaction rather than subject matter or programming are seen as being primarily VMG responsibilities.

To ensure that we had not missed some aspect of VMG programs while preparing the survey, we asked two openend questions: "What do you think is the single most important thing you have accomplished as a volunteer through MG?" and "What do you think is the single most important contribution that the MG program has made in your community?" Answers to each question were grouped according to similarity. Ultimately, the same five groups were arrived at for each question. The groupings with a representative response to each question follow:

\section{Providing information}

- "Bringing accurate horticultural information to the public at a reasonable cost."

- "Provides an unbiased source by which the public can ask questions and receive answers before they ask the same question of a commercial salesperson who knows little, if anything, about what they speak."

Helping people while helping the environment

- "I used my experience and training to help others, so we can all help our community and environment. "

- "To make people more aware of the needs for plants in our environment."

\section{Improving the community}

- "Took an eyesore and converted it into a beautiful flower bed. This was public property, and no money was available to. improve it."

-" Showing local people that we can work together to help beautify our city, starting out in a small way perhaps to 'grow' larger through many small efforts." 
Table 5. Responsibilities for Virginia Master Gardener program elements (\% response).

\begin{tabular}{|c|c|c|c|}
\hline & $\begin{array}{l}\text { Agent with } \\
\text { some help } \\
\text { from a MG }\end{array}$ & $\begin{array}{l}\text { Master Gardener } \\
\text { in cooperation } \\
\text { with agent }\end{array}$ & $\begin{array}{c}\text { Master Gardener } \\
\text { through a MG } \\
\text { association }\end{array}$ \\
\hline \multicolumn{4}{|l|}{ Scheduling and conducting annual } \\
\hline Master Gardener training & 61 & '34 & 5 \\
\hline \multicolumn{4}{|l|}{ Deciding what activities Master } \\
\hline Gardeners will undertake & 21 & 57 & 22 \\
\hline $\begin{array}{l}\text { Detailed daily management of Master } \\
\text { Gardener projects (i.e., schedules of } \\
\text { plant clinic volunteers) }\end{array}$ & 16 & 56 & 28 \\
\hline \multicolumn{4}{|l|}{ Keeping records to document impact } \\
\hline \multicolumn{4}{|l|}{$\begin{array}{l}\text { Field trips/Social/Continuing educa- } \\
\text { tion programming for established }\end{array}$} \\
\hline Master Gardeners & 15 & 51 & 34 \\
\hline \multicolumn{4}{|l|}{ Establishing and managing local Master } \\
\hline $\begin{array}{l}\text { Gardener associations (either formal or } \\
\text { informal) }\end{array}$ & 14 & 50 & 36 \\
\hline $\begin{array}{l}\text { Communications systems, newsletters } \\
\text { among Master Gardeners }\end{array}$ & 14 & 40 & 46 \\
\hline \multicolumn{4}{|l|}{ Participating in State Master Gardener } \\
\hline Advisory Board & 12 & 33 & 55 \\
\hline
\end{tabular}

Becoming better educated; therefore, a better citizen

- "Learned a lot and became aware of how much valuable information and training I'd had throughout my life that I could share."

- "The community has benefited from the education of individuals in the program who have then used that education to aid them in the proper care of plant life and the ecologically sound practices of gardening, planting, landscaping, etc."

Influencing government through support and interaction - "Worked with state legislators to insure continued funding of Extension Service programs."

- "Saving the state untold thousands of dollars with our many volunteer hours toward unfunded, but necessary, programs."

MGs have evolved over the years from primarily being "volunteers with gardening answers" to providing programs to improve the environment and communities. From this study, it is clear that VMGs perceive the work they are doing to have value to themselves and their community. They are willing to take on significant responsibility in the management of the program to ensure that it continues as a part of cooperative extension.

By understanding MG priorities for extension programs, agents can better use their talents and motivate them to reach shared goals. Recognition of MG perception that most of the management of a MG program is their responsibility can be extremely useful in encouraging agents to delegate these jobs. A concern often expressed by agents is that a MG program will increase the workload due to new management responsibilities. Based on this survey, this does not have to be the case.

A theme that became clear from the comments of the respondents is that the MG program has a significant role in developing community leaders who strongly support extension. As MGs increase both their horticultural and educational / community development skills, they become strong representatives of extension. In addition, they serve as spokespersons for consumer horticulture in much the same way trade associations do for the industry.

\section{Literature Cited}

Flagler, J.S. 1992. Master Gardeners and horticultural therapy. HortTechnology 2(2):249-250.

Grieshop, J.J. 1984. Serendipity and community development A study of unplanned community development consequences on a community service program. J. Community Dev. Soc. 15(2):87103.

Stouse, L. and C. Marr. 1992. Retaining Master Gardener volunteers. HortTechnology 2(2):244-245.

Voluntary Action Leadership. 1992. IS survey show Americans generous even in hard times; more than half still volunteer. Voluntary Action Leadership Fall 1992. p. 27,29.

Warner, J. C. 1978. A survey study of the Master Gardener, a Cooperative Extension Service program. MS Thesis. Ohio State Univ., Columbus. 